Science, Technology and Development 35 (3): 123-127, 2016

ISSN 0254-6418 / DOI: 10.3923/std.2016.123.127

(C) 2016 Pakistan Council for Science and Technology

\title{
Different Growth Media Effect the Germination and Growth of Tomato Seedlings
}

\author{
Muhammad Jawaad Atif, Ghulam Jellani, Muhammad Humair Ahmed Malik, Noor Saleem, \\ Hidayat Ullah, Muhammad Zameer Khan and Samia Ikram \\ National Agricultural Research Centre, Pakistan Agricultural Research Council, Islamabad, Pakistan
}

\begin{abstract}
Effect of peat, compost (vegetable waste) and traditional practicing media (soil, sand and farmyard manure) alone and in combinations, was examined on the quality of tomato seedlings (Lycopersicon esculentum L.) at Directorate of Vegetable, DHRD, NARC, Islamabad, during 2013-14. Germination and several seedling quality variables, like, days to emergence, shoot length, height, vigor index, dry matter accumulation and benefit cost ratio, were monitored. Maximum germination percentage (95), seedlings shoot length $(26.67 \mathrm{~cm})$, seedling height $(35 \mathrm{~cm})$, seedling vigor index (3325) and minimum days to emergence (15.33) were observed in $T_{9}$ (peat, compost and traditional practicing media in 1:1:1 ratio). Maximum dry matter accumulation (34.80\%) was recorded in $\mathrm{T}_{1}$ (peat). Maximum benefit cost ratio (2.70) is calculated for $\mathrm{T}_{0}$ : traditional practicing media (soil, sand and farmyard manure in 1:1:1 ratio). Optimum growth of tomato seedlings was observed when peat, compost and traditional practicing media were used in equal proportions.
\end{abstract}

Key words: Tomato, seedlings, peat, peat substitutes (compost and traditional media)

\section{INTRODUCTION}

Tomato (Lycopersicon esculentum L.) from family solanaceae is popular cultivated vegetable in the world and is famous for its nutritive and medicinal value (Opena and Kyomo, 1990). It is 2nd most consumed after potato, ranks 1 st among the processing crops and undeniably most popular garden crop (Kalia and Palanisamy, 2014). Among vegetables, tomato is the 2nd major vegetable, produced in Pakistan. It is grown on 173.36 in Kharif and 455.94 square kilometer in Rabi season with average yield of 145.872 thousand tons in Kharif and 453.72 thousand tons in Rabi season in Pakistan (GOP., 2014). It is a cheap source of vitamins (A, C, E), calcium, niacin and minerals (Olaniyi et al., 2010). Tomatoes grow best at temperatures 20-27 ${ }^{\circ} \mathrm{C}$.

Healthy seedlings production is prerequisite for raising vigorous and profitable crops. Seedlings are grown in different growth media, which plays a vital role in efficient production of horticultural seedlings in nurseries (Sterrett, 2001). Soilless substrates have been used for the production of horticultural crops in containers, including organic materials, such as, peat moss. Peat is collected from bogs, marshes, and wetlands, which are often fragile ecosystems of great ecological and archaeological value (Bustamante et al., 2008). Peat moss, due to its appropriate physical properties, such as, low bulk density and high total porosity and its high nutrient exchange capacity constitute one of the main substrate components for seedling production in containers (Abad et al., 2001; Maher et al., 2008). Use of peat for growing seedlings is however expensive.

Many authors have indicated the feasibility of vegetable waste composts, solid urban wastes and the residues of the wine industry as seedbed substrates for the production of horticultural seedlings in nurseries (Castillo et al., 2004; Garcia-Gomez et al., 2002; Herrera et al., 2008; Kostov et al., 1996; Perez-Murcia et al., 2006). Use of vegetable composts also results in their safe disposal and hence there is no environmental risk as well. It is estimated that about $40 \%$ of vegetables in the country are wasted due to poor handling during the harvesting and lack of storage facilities. Vegetable waste left behind during harvest, lying unused and unwanted in farm fields and processing plant, can be used to grow horticultural seedlings in order to achieve good crops. Use of mixtures of compost with peat can diminish the possible poor properties of single materials, such as, high salinity, heterogeneity, or high content of pollutants (Raviv et al., 1986). Therefore, the proportion of compost in the growing media is essential to decrease potential hazards, especially salinity (Bustamante et al., 2008). Keeping in view, the importance of peat and vegetable waste compost for the production of seedling this research work focused at production of quality seedling with desired morphological and physiological features that guarantee crop success after transplanting using economical growth media was the main objective of the study. 
Sci. Technol. Dev., 35 (3): 123-127, 2016

\section{MATERIALS AND METHODS}

The experiment was carried out at the experimental field of Directorate of Vegetable, DHRD, NARC, Islamabad, during 2013-14. The experimental site is located at $73.08^{\circ}$ (longitude), $33.42^{\circ}$ (latitude) and 683 msl (elevation) on the global scale. The experiment was conducted under plastic tunnel. Seedlings of tomato (var. Riogrande) were raised in multiport trays. Peat and peat substitutes (compost and traditional practicing media) alone or in combinations were tested for economical and successful growth of tomato seedlings. Plants were periodically and equally irrigated, but no additional nutrient elements were supplied all nursery time. The experimental treatments were arranged in a completely randomized design (CRD), i.e., $\mathrm{T}_{0}$ : Traditional practicing media (soil, sand and farmyard manure in 1:1:1 ratio), $\mathrm{T}_{1}$ : Peat, $\mathrm{T}_{2}$ : Compost, $\mathrm{T}_{3}$ : Peat and compost (1:1), $\mathrm{T}_{4}$ : Peat and compost (1:1/2), $T_{5}$ : Peat and compost (1/2:1), $\mathrm{T}_{6}$ : Peat and traditional practicing media (1:1), $\mathrm{T}_{7}$ : Peat and traditional practicing media (1:1/2), $\mathrm{T}_{8}$ : Peat and traditional practicing media (1/2:1), $\mathrm{T}_{9}$ : Peat, compost and traditional practicing media (1:1:1). Each treatment was replicated thrice. Germination percentage, days to emergence, seedling shoot length $(\mathrm{cm})$, seedling height $(\mathrm{cm})$, seedling vigor index, dry matter accumulation (mg/05 seedling) and benefit cost ratio were recorded. Seedling vigor index is calculated by multiplying germination (\%) and seedling length. The seedling showing the higher seedling vigor index is considered to be more vigorous (Abdul-Baki and Anderson, 1973). Data were subjected to analysis of variance (ANOVA) to compare the effects of media. The differences between the means were compared, using the least significant difference test (LSD, p<0.05), (Steel et al., 1997). All statistical tests were conducted using the Statistix 8.1 software package. Germination percentage, seedling vigor index and dry accumulation percentage was calculated, using the following formulae:

$$
\text { Germination }(\%)=\frac{\text { Seeds germinated }}{\text { Total No. of seeds }} \times 100
$$

Seedling vigor index $=$ Germination $(\%) \times($ Shoot length + Root length $)(2)$

$$
\text { Dry metters accumulation (\%) }=\frac{\text { Dry weight }}{\text { Fresh weight }} \times 100
$$

BCR was calculated by the following formula (Asaduzzaman et al., 2011).

$$
B C R=\frac{\sum_{i=1}^{t} \frac{B_{t}}{(1+r)^{t}}}{\sum_{t=0}^{t} \frac{C_{t}}{(1+r)^{t}}}
$$

Where:

B : Benefits of the project

C : Cost of the project

$\mathrm{t}$ : Time measured in years

$r$ : Discount rate

Organic matter content (\%) was estimated by Loss-On-Ignition method (Atkinson et al., 1958), while modified Walkley-Black procedure (Nelson and Sommers, 1982) was adopted for the determination of organic carbon. Total nitrogen and phosphorus contents (\%) were determined by the method described by Cleaver (1966). Potassium (\%) was determined by Kjeldahl and Flannery (1975). Zinc, Fe, $\mathrm{Cu}$ and Mn $\left(\mathrm{mg} \mathrm{kg}^{-1}\right)$ were determined by dry ash method (Issac and Johnson, 1975). Ash content was determined by AOAC (1994). The nutrient composition of different ratio of media is given in Table 1 .

\section{RESULTS AND DISCUSSION}

Results related to germination percentage, days to

\begin{tabular}{|c|c|c|c|c|c|c|c|c|c|c|}
\hline Treatment & $\begin{array}{l}\text { Ash } \\
\text { content (\%) }\end{array}$ & $\begin{array}{l}\text { Organic } \\
\text { matter (\%) }\end{array}$ & $\begin{array}{l}\text { Organic } \\
\text { carbon (\%) }\end{array}$ & $\begin{array}{l}\text { Total N } \\
(\%)\end{array}$ & $\begin{array}{l}\text { Total P } \\
(\%)\end{array}$ & $\mathrm{K}(\%)$ & $\mathrm{Zn}\left(\mathrm{mg} \mathrm{kg}{ }^{-1}\right)$ & $\mathrm{Fe}\left(\mathrm{mg} \mathrm{kg}^{-1}\right)$ & $\mathrm{Cu}\left(\mathrm{mg} \mathrm{kg}^{-1}\right)$ & $\operatorname{Mn}\left(\mathrm{mg} \mathrm{kg}^{-1}\right)$ \\
\hline$\overline{\mathrm{T}_{0}}$ & 0.18 & 99.82 & 57.90 & 0.76 & 1.46 & 0.09 & 70.8 & 3.4 & 39.2 & 76.8 \\
\hline $\mathrm{T}_{1}$ & 1.33 & 98.67 & 57.23 & 0.54 & 2.41 & 0.14 & 159.0 & 4.2 & 43.2 & 311.6 \\
\hline $\mathrm{T}_{2}$ & 1.33 & 98.87 & 57.34 & 0.47 & 2.37 & 0.15 & 118.6 & 3.6 & 34.8 & 237.6 \\
\hline $\mathrm{T}_{3}$ & 0.86 & 99.14 & 57.50 & 0.44 & 2.17 & 0.15 & 110.0 & 1.6 & 36.0 & 217.8 \\
\hline $\mathrm{T}_{4}$ & 1.08 & 98.92 & 57.37 & 0.54 & 1.58 & 0.09 & 92.4 & 3.6 & 31.8 & 241.2 \\
\hline $\mathrm{T}_{5}$ & 1.21 & 98.79 & 57.30 & 0.36 & 1.52 & 0.09 & 83.8 & 1.8 & 27.6 & 189.6 \\
\hline $\mathrm{T}_{6}$ & 1.45 & 98.55 & 57.16 & 0.19 & 1.46 & 0.09 & 72.2 & 0.6 & 30.2 & 136.4 \\
\hline $\mathrm{T}_{7}$ & 1.49 & 98.51 & 57.14 & 0.25 & 1.68 & 0.09 & 81.4 & 3.6 & 34.8 & 169.0 \\
\hline $\mathrm{T}_{8}$ & 1.30 & 98.70 & 57.25 & 0.41 & 1.42 & 0.09 & 112.4 & 4.0 & 29.8 & 208.6 \\
\hline $\mathrm{T}_{9}$ & 1.70 & 98.30 & 57.01 & 0.22 & 1.76 & 0.09 & 68.6 & 8.0 & 26.8 & 210.0 \\
\hline
\end{tabular}
emergence, seedling height $(\mathrm{cm})$, seedling vigor index,

Table 1: Nutrient composition of different ratios of media 
Sci. Technol. Dev., 35 (3): 123-127, 2016

Table 2: Comparison of peat and peat substitutes for tomato seedling production

\begin{tabular}{|c|c|c|c|c|c|c|c|}
\hline Treatment & Germination (\%) & Days to emergence & $\begin{array}{l}\text { Seedling shoot } \\
\text { length }(\mathrm{cm})\end{array}$ & $\begin{array}{l}\text { Seedling height } \\
(\mathrm{cm})\end{array}$ & $\begin{array}{l}\text { Seedling vigor } \\
\text { index }\end{array}$ & $\begin{array}{l}\text { Dry matter } \\
\text { accumulation (\%) }\end{array}$ & Cost benefit \\
\hline$\overline{\mathrm{T}_{0}}$ & $84.10^{\mathrm{i}}$ & $23.67^{\mathrm{a}}$ & $12.67^{g}$ & $19.00^{\mathrm{g}}$ & $1598.0^{\mathrm{i}}$ & $33.20^{\mathrm{a}}$ & 2.70 \\
\hline $\mathrm{T}_{1}$ & $85.27^{\mathrm{h}}$ & $22.33^{\mathrm{b}}$ & $15.00^{\mathrm{e}}$ & $23.00^{f}$ & $1961.5^{\mathrm{h}}$ & $34.80^{\mathrm{a}}$ & 0.18 \\
\hline $\mathrm{T}_{2}$ & $87.07^{\mathrm{g}}$ & $22.00^{\mathrm{bc}}$ & $16.67^{\mathrm{e}}$ & $24.67^{\mathrm{e}}$ & $2147.6^{\mathrm{g}}$ & $28.97^{\mathrm{bc}}$ & 2.62 \\
\hline $\mathrm{T}_{3}$ & $89.10^{f}$ & $21.00^{\text {cd }}$ & $18.33^{\mathrm{d}}$ & $26.33^{\mathrm{d}}$ & $2346.3^{f}$ & $35.20^{\mathrm{a}}$ & -0.15 \\
\hline $\mathrm{T}_{4}$ & $91.10^{\mathrm{e}}$ & $20.33^{\mathrm{de}}$ & $20.00^{c}$ & $28.00^{c}$ & $2550.9^{\mathrm{e}}$ & $26.33^{\text {cd }}$ & 0.21 \\
\hline $\mathrm{T}_{5}$ & $91.90^{\mathrm{d}}$ & $19.33^{\mathrm{ef}}$ & $21.00^{c}$ & $29.33^{c}$ & $2695.7^{\mathrm{d}}$ & $28.17^{\mathrm{bcd}}$ & 0.54 \\
\hline $\mathrm{T}_{6}$ & $92.90^{c}$ & $18.33^{f}$ & $21.00^{c}$ & $31.67^{b}$ & $2941.8^{c}$ & $29.17^{\mathrm{bc}}$ & -0.17 \\
\hline $\mathrm{T}_{7}$ & $87.07^{\mathrm{g}}$ & $16.67^{\mathrm{g}}$ & $21.00^{c}$ & $33.67^{\mathrm{a}}$ & $3138.8^{\mathrm{b}}$ & $22.93^{\mathrm{e}}$ & -0.18 \\
\hline $\mathrm{T}_{8}$ & $94.23^{\mathrm{b}}$ & $16.00^{\mathrm{gh}}$ & $26.33^{\mathrm{a}}$ & $34.00^{\mathrm{a}}$ & $3204.0^{\mathrm{ab}}$ & $26.00^{\mathrm{d}}$ & 0.11 \\
\hline $\mathrm{T}_{9}$ & $95.000^{\mathrm{a}}$ & $15.333^{\mathrm{h}}$ & $26.667^{\mathrm{a}}$ & $35.000^{\mathrm{a}}$ & $3325.0^{\mathrm{a}}$ & $30.100^{\mathrm{b}}$ & 1.58 \\
\hline LSD & 0.42 & 1.24 & 1.31 & 1.59 & 142.91 & 2.88 & \\
\hline
\end{tabular}

dry matter accumulation percentage and cost benefit ratio are summarized in Table 1 . The highest germination percentage (95), seedlings shoot length $(26.67 \mathrm{~cm})$, seedling height $(35 \mathrm{~cm}$ ), seedling vigor index (3325) and minimum days to emergence (15.33) were observed, whereas peat, compost and traditional media were used in equivalent ratio (1:1:1). Increase in the above-mentioned parameters might be due to higher phosphorous content, due to equivalent ratio of peat, compost and traditional practicing media. Phosphorous is involved in the formation of energy rich compounds, which in return derive various bio-chemical reactions within the plant include adenosine triphosphate and adenosin diphosphate (Memon, 1996). Balanced proportion of $\mathrm{Zn}, \mathrm{Cu}, \mathrm{Fe}$ and Mn may also have promoted the growth of the seedlings. Our results were in line with various scientists, such as, Riaz et al. (2008), advocated use of different growing media for zinnia and suggested physical and chemical properties of media, like, structure, texture, $\mathrm{pH}$, as well as, nitrogen, phosphorus and potassium, as a dominant factor for the growth and development of plant. Furthermore, Ahmad et al. (2012) suggested that incorporation of rice hulls and press mud in traditional substrates improved the growth and quality indices and increased flower yield of Rosa hybrid L. cvs. 'Kardinal', 'Anjlique' and 'Gold Medal'.

Maximum dry matter accumulation (34.80\%) was recorded in $\mathrm{T}_{1}$ (peat). The data regarding Benefit Cost Ratio (BCR) of seedling produced in different planting medias explicated in Table 2, which elaborates that maximum profit (2.70) can be earned, using $\mathrm{T}_{0}$ : traditional practicing media (soil, sand and farmyard manure in 1:1:1 ratio). The world is shifting from peat moss to other planting media, such as compost, etc., because peat moss is a scarce and expensive growth media, in order to reduce cost and environmental concerns substitutes (compost, vermi-compost, sand, farmyard manure and poultry manure, etc.) of peat became the best choice either alone or in combination with each other (Abad et al., 2001). The results of our findings are in line with aforesaid statement. Previous studies showed that the organic media had greater $\mathrm{P}$ and $\mathrm{K}$ levels than the commercial media (Amassa and Manenoi, 2008). Our results show greater growth of tomato seedlings with the use nutrient rich composted media, which were also observed by other researchers, such as, with the use of composted rice straw, poultry manure and banana waste mixed with peat moss, show better growth of tomato seedlings (Nadia et al., 2007). Herrera et al. (2008) found that tomato sown on $65 \%$ white peat (WP) mixed with $30 \%$ municipal solid waste compost (MSWC) had better quality seedlings than those grown with standard peat mixtures, old peat mixtures and with WP+MSWC mixtures that had a high proportion of MSWC. In this study, we found that a lack of available essential nutrients in the growth media resulted in reduced-seedling growth. Our results were similar to the $\mathrm{Mg}$ and $\mathrm{K}$ deficiency symptoms observed on Khayaivorensis seedlings which resulted in poor growth and lesser nutrient tissue levels (Jeyanny et al., 2009).

The most suitable treatment for vegetative variables of seedlings is $\mathrm{T}_{9}$ (peat, compost and traditional practicing media in 1:1:1 ratio), whereas the most economical treatment for seedling production is $\mathrm{T}_{0}$ : Traditional practicing media (soil, sand and farmyard manure in 1:1:1 ratio).

\section{CONCLUSION}

This study shows that the most suitable treatment for vegetative variables of seedlings is $T_{9}$ (peat, compost and traditional practicing media in 1:1:1 ratio) whereas the most economical treatment for seedling production is $\mathrm{T}_{0}$ : Traditional practicing media (soil, sand and farmyard manure in 1:1:1 ratio).

\section{REFERENCES}

AOAC., 1994. Official Methods of Analysis. 15th Edn., Association of Official Analytical Chemists, Washington, DC. 
Abad, M., P. Noguera and S. Bures, 2001. National inventory of organic wastes for use as growing media for ornamental potted plant production: Case study in Spain. Bioresour. Technol., 77: 197-200.

Abdul-Baki, A.A. and J.D. Anderson, 1973. Vigor determination in soybean seed by multiple criteria. Crop Sci., 13: 630-633.

Ahmad, I., M.A. Khan, M. Qasim, M.S. Zafar and R. Ahmad, 2012. Substrates effects on growth, yield and quality of Rosa hybrida L. Pak. J. Bot., 44: 177-185.

Amassa, P. and A. Manenoi, 2008. On-farm organic media production, using local materials within the Northeast, Thailand. Adams Enterprises Ltd., Northeast, Thailand.

Asaduzzaman, M., A. Naseem and R. Singla, 2011. Benefit-cost assessment of different homestead vegetable gardening on improving household food and nutrition security in rural Bangladesh. Agricultural and Applied Economics Association's 2011. AAEA and NAREA Joint Annual Meeting, Pittsburgh, Pennsylvania, July, 2011.

Atkinson, H.J., G.R. Giles, A.J. Maclean and J.R. Wright, 1958. Chemical methods of soil analysis. Chemistry Division-Science Service Contribution No. 169, Department of Agriculture, Ottawa.

Bustamante, M.A., C. Paredes, R. Moral, E. Agullo, M.D. Perez-Murcia and M. Abad, 2008. Composts from distillery wastes as peat substitutes for transplant production. Resourc. Conserv. Recycl., 52: 792-799.

Castillo, J.E., F. Herrera, R.J. Lopez-Bellido, F.J. Lopez-Bellido, L. Lopez-Bellido and E.J. Fernandaze, 2004. Municipal Solid Waste (MSW) compost as a tomato transplant medium. Compost Sci. Util., 12: 86-92.

Cleaver, T.J., 1966. Routine determination of N, P, K, Ca, $\mathrm{Mg}$ and $\mathrm{N}$ in plant material. The National Vegetable Research Station, Wellesbourne, Warwick.

GOP., 2014. Fruits, vegetables and condiments: Statistics of Pakistan. Ministry of National Food Security and Research (Economic Wing), Islamabad.

Garcia-Gomez, A., M.P. Bernal and A. Roig, 2002. Growth of ornamental plants in two composts prepared from agroindustrial wastes. Bioresour. Technol., 83: 81-87.

Herrera, F., J.E. Castillo, A.F. Chica and L. Lopez-Bellido, 2008. Use of municipal solid waste compost (MSWC) as a growing medium in the nursery production of tomato plants. Bioresourc. Technol., 99: 287-296.
Issac, R.A. and W.C. Johnson, 1975. Collaborative study of wet and dry ashing techniques for elemental analysis of plant tissue by atomic absorption spectroscopy. J. Assoc. Off. Anal. Chem., 58: 436-440.

Jeyanny, V., A.G.A. Rasip, K.W. Rasidah and Y.A. Zuhaidi, 2009. Effects of macronutrient deficiencies on the growth and vigour of khaya ivorensis seedlings. J. Trop. For. Sci., 21: 73-80.

Kalia, P. and M. Palanisamy, 2014. Tomato. In: Alien Gene Transfer in Crop Plants, Volume 2: Achievements and Impacts, Pratap, A. and J. Kumar (Eds.)., Springer, New York, USA., pp: 347-381.

Kjeldahl, S.E. and R.L. Flannery, 1975. Automatic determination of phosphorus and potassium in wet digestion solution of plant tissue. Proceedings of the Technicon Symposium on Automation in Analytical Chemistry, (TSAAC'75), Mediad Inc., New York, pp: 116-122.

Kostov, O., Y. Tzvetkov, N. Kaloianova and O. van Cleemput, 1996. Production of tomato seedlings on composts of vine branches and grape prunings, husks and seeds. Compost Sci. Util., 4: 55-61.

Maher, M., M. Prasad and M. Raviv, 2008. Organic Soilless Media Components. In: Soilless Culture: Theory and Practice, Raviv, M. and J.H. Lieth (Eds.)., Elsevier, London, UK., ISBN: 9780080556420, pp: 459-504.

Memon, K.S., 1996. Soil and Fertilizer Phosphorus. In: Soil Science, Bashir, E. and R. Bantel (Eds.). National Book Foundation, Islamabad, pp: 291-316.

Nadia, M.B., O.H. El-Hussieny and E.H. Allam, 2007. Efficiency of some natural substitutes of peatmoss as growing media for tomato seedlings production. Aust. J. Basic Applied Sci., 1: 193-207.

Nelson, D.W. and L.E. Sommers, 1982. Total Carbon, Organic Carbon and Organic Matter. In: Methods of Soil Analysis, Part 2: Chemical and Microbiological Properties, Page, A.L., R.H. Miller and D.R. Keeney (Eds.). 2nd Edn., ASA and SSSA, Madison, WI., USA., pp: 539-579.

Olaniyi, J.O., W.B. Akanbi, T.A. Adejumo and O.G. Akande, 2010. Growth, fruit yield and nutritional quality of tomato varieties. Afr. J. Food Sci., 4: 398-402.

Opena, R.T. and M.L. Kyomo, 1990. Vegetable research and development in SADCC countries: Proceedings of workshop held at Arusha, Tanzania, 9-13 July, 1990. AVRDC Publication No. 90-328, Canada. 
Perez-Murcia, M.D., R. Moral, J. Moreno-Caselles, A. Perez-Espinosa and C. Paredes, 2006. Use of composted sewage sludge in growth media for broccoli. Bioresourc. Technol., 97: 123-130.

Raviv, M., Y. Chen and Y. Inbar, 1986. Peat and Peat Substitutes as Growth Media for Container-grown Plants. In: The Role of Organics Matter in Modern Agriculture, Chen, Y. and Y. Avnimelech (Eds.). Martinus Nijhoff Publications, Hague Netherland, pp: 257-287.

Riaz, A., M. Arshad, A. Younis, A. Raza and M. Hameed, 2008. Effects of different growing media on growth and flowering of zinnia elegans $\mathrm{cv}$. blue point. Pak. J. Bot., 40: 1579-1585.
Steel, G.D. and J.H. Torrie and D.A. Dickey, 1997. Principles and Procedures of Statistics: A Biometrical Approach. 2nd Edn., McGraw-Hill Book, New York, pp: 636.

Sterrett, S.B., 2001. Compost as Horticultural Substrates for Vegetable Transplant Production. In: Compost Utilization in Horticultural Crooping Systems, StoVella, P.J. and B.A. Kahn (Eds.). Lewis Publication, Boca Raton, FL, pp: 227-240. 